\title{
By the rivers of Nova Nadezhda: dynamics of human-environment interaction at a prehistoric site in Upper Thrace
}

\author{
Marlena Yaneva1, Nadezhda Todorova², Georgi Katsarov², Vanya Petrova², \\ Krum Bacvarov ${ }^{3}$
}

${ }^{1}$ Geological Institute, Bulgarian Academy of Sciences, Acad. G. Bonchev Str., Bl. 24, 1113 Sofia, Bulgaria; e-mail: marlena@geology.bas.bg

${ }^{2}$ University of Sofia "St Kliment Ohridski”, Faculty of History, Department of Archaeology, 15 Tsar Osvoboditel Blvd, 1000 Sofia,Bulgaria; e-mails: ntodorovabg@yahoo.com,gkatzarov@yahoo.com

${ }^{3}$ National Institute of Archaeology and Museum, Bulgarian Academy of Sciences, Department of Prehistory, 2 Saborna Str., 1000 Sofia,Bulgaria; e-mail: krum.bacvarov@gmail.com

(Accepted in revised form: November 2017)

\begin{abstract}
The archaeological site of Nova Nadezhda is located on a T1 terrace on the right bank of the Maritsa River and on the left bank of its right tributary, the Dermen Dere stream. Comparison of the grain-size and mineral composition of sediments from the site and natural deposits from the Maritsa and the Dermen Dere suggests that the stream recurrently flooded the eastern part of the site in the later prehistory $\left(6^{\text {th }}\right.$ and $5^{\text {th }}$ mill. BC) and later shifted its course to the east. Terrace sediments and later incisions of the Maritsa and the Dermen Dere are obvious in 2D resistivity images.
\end{abstract}

Yaneva, M., N. Todorova, G. Katsarov, V. Petrova, K. Bacvarov. 2017. By the rivers of Nova Nadezhda: dynamics of human-environment interaction at a prehistoric site in Upper Thrace. Geologica Balcanica 46 (2), 65-72.

Keywords: archaeology, geology, sedimentology, later prehistory.

\section{INTRODUCTION}

Fluvial environments as floodplains and river terraces have always been attractive for human occupation as they provide water supply, fertile soil for agriculture, source of food, and easy transport. On the negative side, periods of intense water activity can seriously endanger and disturb the normal life of a settlement, especially in ancient times when people had less control over their environment. Evidence of water-induced damage has often been identified in the archaeological record, challenging archaeologists to collect as many data as possible in order to elaborate a plausible model of the dynamics of human-environment interaction and to get further insights into the social mechanisms of coping with environmental stress. Such is the case of the archaeological site of Nova Nadezhda on the Maritsa River in Upper Thrace, southeast Bulgaria, where excavations revealed evidence of multiple flood events that had resulted in considerable disturbances of archaeological deposits and triggered significant changes in the lifeways of local community.
In this paper, we examine the position of the prehistoric site of Nova Nadezhda with respect to the Maritsa River terrace and its tributary, the Dermen Dere stream, using geological and geophysical methods, and shortly discuss the results of a geological field survey undertaken in the vicinity of the modern village of Nova Nadezhda in order to gain better understanding of the fluvial and environmental setting of the archaeological site.

\section{ARCHAEOLOGICAL SETTING}

The site of Nova Nadezhda was identified during archaeological monitoring in advance of a railroad reconstruction project, after scraping off the topsoil. It is situated on a low-lying terrace in the fertile floodplain of the Middle Maritsa Valley, $\sim 300 \mathrm{~m}$ from the river's right bank, and covers an area of over 5 ha (Fig. 1). The core area of the site consists of two tell-like formations, a northwest (ca 140 $\times 120 \mathrm{~m}$ ) and a southeast one (ca $150 \times 130 \mathrm{~m}$ ), $89 \mathrm{~m}$ and $92.68 \mathrm{~m}$ amsl, respectively, 


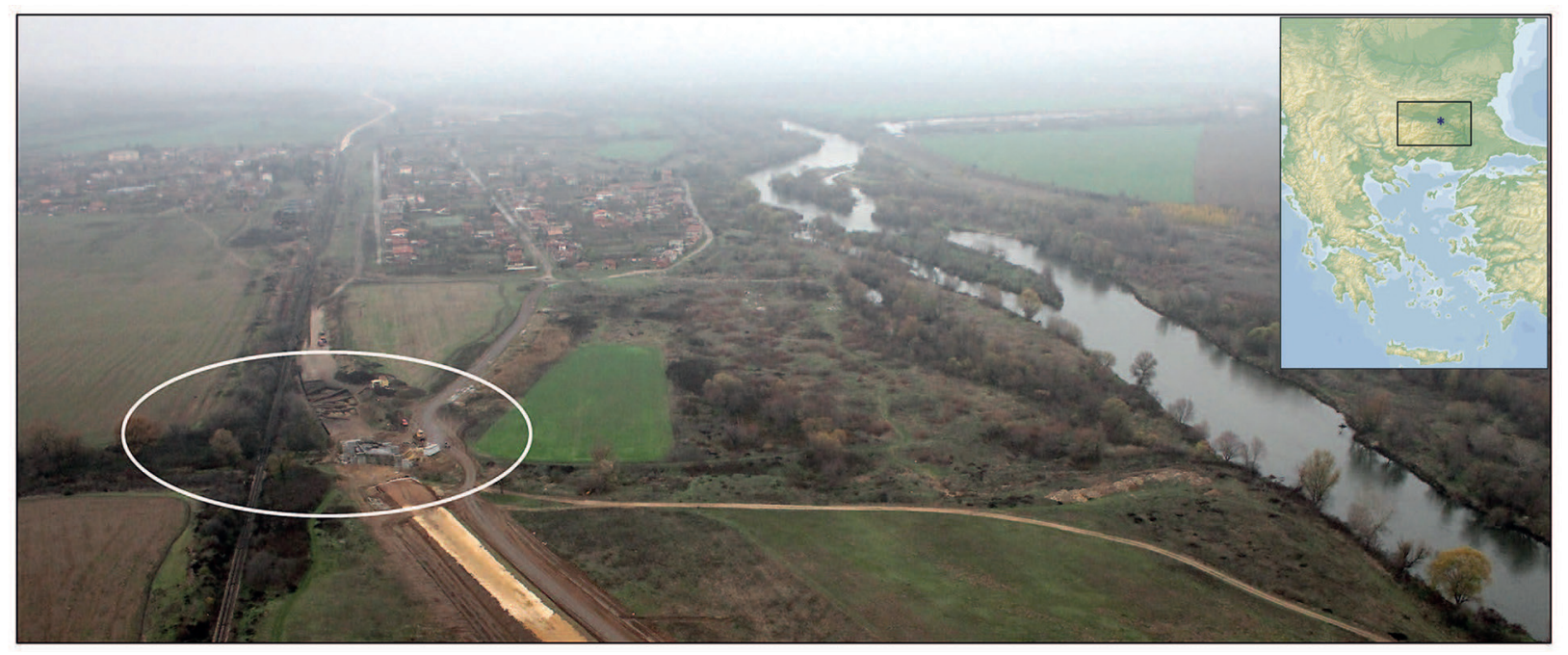

Fig. 1. Aerial panoramic view of the site of Nova Nadezhda, with the Maritsa River running to the north, and map showing the location of the site (after Bacvarov et al., 2016).

divided by the Dermen Dere ravine, with a stream running along the bottom and flowing downslope into the Maritsa. Rescue excavations of an area of $\sim 7500 \mathrm{~m}^{2}$ took place at the north edge of the northwest tell in 2013-2014 (Bacvarov et al., 2016).

Several major occupation periods were recorded at the excavated area. The site was continually occupied from the beginning of the Early Neolithic (ca 6000 calBC) to the Final Chalcolithic (ca 4000 calBC), and then again in the Early Iron Age (11th-9th centuries calBC). In the 17 th and 18 th centuries $\mathrm{AD}$, the east and northeast slopes of the tell were used as a cemetery by a nearby Muslim village community. Although no excavations were carried out at the southeast tell, the results of a surface survey seem to suggest that it was occupied more or less simultaneously, as well as in the Early Bronze Age.

The Early Neolithic occupation area is located in the east parts of the northwest tell-like formation, immediately west of the Dermen Dere ravine. The northnorthwest segments of five concentric enclosure ditches were revealed that had been used successively, the innermost being the earliest and the outermost being the latest. As was also shown by geomagnetic mapping, they all enclose a round/oval surface from the north, west, and south. To the east, they connect to the west edge of the ravine, which in the sixth millennium $\mathrm{BC}$ was much deeper and had a steep west slope.

In the late sixth and early fifth millennia calBC (Late Neolithic and Early Chalcolithic), possibly due to the high water table, the occupation area shifted to the west-southwest. The east parts of the northwest tell were later re-occupied, but the Late Chalcolithic deposits were washed down and almost completely filled in the ravine in several short-spaced and cataclysmic flood events that were radiocarbon and stratigraphi- cally dated to ca 4500/4400 calBC. In the Final Chalcolithic, this area was settled again, as shown by the burnt remains of a large house. The recurrent flooding continued throughout the Early Iron Age, when the west part of the tell was occupied by a small village.

\section{GEOLOGICAL SETTING}

The archeological site of Nova Nadezhda is located in the Upper Thracian Depression. The latter is a grabenlike structure, $130-145 \mathrm{~m}$ above sea level, bordered by the Sredna Gora Mountains to the north and the Rhodope Mountains to the south, the range fronts of which are at an altitude of ca $1000 \mathrm{~m}$ and $1500 \mathrm{~m}$, respectively. The graben is filled by continental sediments up to $1300 \mathrm{~m}$ thick (Krastev et al., 1992; Zagorchev, 1992). Upper Miocene to Lower Pleistocene alluvial sediments of the Ahmatovo Formation (Kojumdgieva and Dragomanov, 1979) and younger deposits of the Maritsa River and its tributaries are widespread in the depression.

The site lies on the T1 terrace of the Maritsa River, which is $8-10 \mathrm{~m}$ above the river bed and consists of clayey/sandy materials, 2-3 m thick (Angelova et al., 1993).

The area of the archaeological site is built of fluvial deposits of the Maritsa River, clastic and carbonate sedimentary rocks, metamorphic rocks of various age, and magmatic rocks (Fig. 2). The youngest deposits, which host the archaeological deposits, are of Quaternary age (Holocene): alluvial deposits of riverbeds and fluvial terraces represented by gravel, sand, and clay. Clastic sedimentary rocks (gravel, sand, clay) of Neogene and Paleogene age outcrop in a widespread strip south (Ahmatovo Formation) and northeast of the 


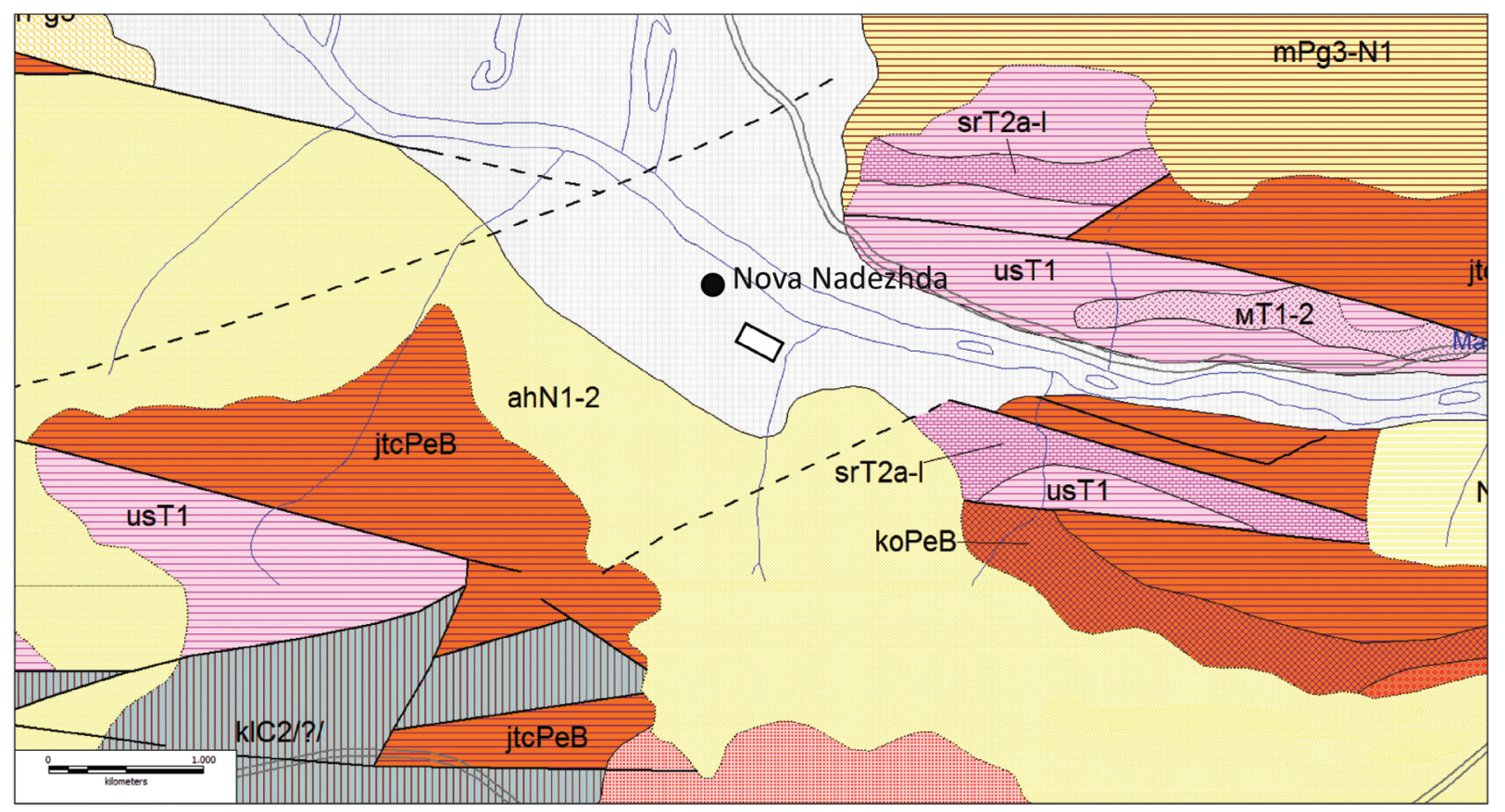

\section{LEGEND}

Quaternary - Alluvial deposits of river beds and fluvial terraces (gravels, sands, clays) $\square$ Neogene-Quaternary - Undivided NeogeneQuaternary deposits (pebbles, cobbles, boulders) anN1-2 Neogene - Ahmatovo Formation (pebbles, gravels, sands, siltstones, sandy clays, infiltration type limestones) Paleogene-Neogene - Maritsa Formation (clays, sands, coal schists, coal) Palaeogene - Bioclastic limestones Triassic - Metamorphosed quartz-porphyric rocks ust1 Triassic - Ustrem Formation (mica schists and mica-granite schists)

Triassic - Srem Formation (metamorphosed limestones and dolostones) || kid2 ||| Carboniferous - Klokotnitsa Formation (metamorphosed

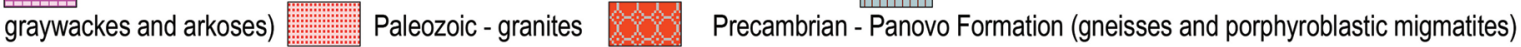

Precambrian - Konstantinovo Formation (metamorphosed conglomerates) jitpee Precambrian - Zhalti Chal Formation (gneisses and schists) Fault _ - Uncertain fault $\diamond$ Archaeological site

Fig. 2. Geological map of the study area (after Boyanov et al., 1993).

Maritsa River (Maritsa Formation). The Ahmatovo Formation represents an alternation of sands, sandy clays, clays and gravels, and infiltration type limestones. The deposits of the older Maritsa Formation are finer: sands, clays, and coal beds. A Paleogene age has been assigned to the bioclastic limestones, based on algae, bryozoans, echinoderms, and mollusks. Widespread metamorphic rocks outcrop in the area, predominantly metaconglomerates, metapsammites, metapelites, gneisses, schists, and metamorphosed limestones and dolostones of Precambrian, Carboniferous, Permian and Triassic age. A body of Paleozoic granites has been found south of the archaeological site.

\section{METHODOLOGY}

The sedimentological study includes a field description of sedimentary successions both in the archaeological profiles and the natural outcrops, grain-size analyses and analyses of the heavy- and light-mineral fraction. In the field description, the structure, texture and color of the sediments were characterized macroscopically. Color indexes were determined, using Munsell color charts. Grain-size analysis was performed by an automatic sieving system FRITSCH ANALYSETTE PRO 3 for fractions above $0.063 \mathrm{~mm}$, and pipette analysis was used for fractions less than $0.063 \mathrm{~mm}$. We used the Udden-Wentworth scale (Wentworth, 1922) to separate the following fractions: gravel $(>2 \mathrm{~mm})$; sand $(2-0.063 \mathrm{~mm})$; silt $(0.063-0.004 \mathrm{~mm})$; and clay $(<0.004 \mathrm{~mm})$. Cumulative curves were drawn and statistical parameters of grain-size distribution were calculated according to Folk (1968): mean size $(\mathrm{Mz})$, standard deviation (sorting $\sigma 1$ ), and skewness Sk (symmetry of distribution).

Mineralogical analysis of the fine sand fraction $(0.063-0.125 \mathrm{~mm})$ after separation into light and heavy fractions by bromoform $\left(\mathrm{CHBr}_{3}\right)$ with density 
$2.89 \mathrm{~g} / \mathrm{cm}^{3}$ was conducted under a polarizing microscope after immersion in eugenol with $n_{e}=1.541$. Quantitative calculations were made on a minimum of 500 mineral grains from the heavy fraction and 300 from the light fraction.

During the archaeological excavations, 2D resistivity profiling was applied to two parallel profiles north of the site. The aim of this work was to clarify the subsurface structure and the distribution of the terrace deposits and the abundant channels of the Dermen Dere stream, and to use the results for palaeoecological reconstruction of the area. For this study, we used a multi-electrode system, consisting of a Terrameter SAS 1000, electrode selector ES 10-64 C, multicabels ( 2 cables $\times 21$ electrodes), electrodes and connecting cables. The survey was carried out by a Schlumberger array ( $200 \mathrm{~m}$ lengths of survey line, $2 \mathrm{~m}$ electrode space). To obtain comparative results, the two profiles were measured by the same Schlumberger array. Measured apparent resistivity data were inverted, using the program Res2Dinv with topographic corrections. An additional model refinement was applied, truncating the electrode spacing to $1 \mathrm{~m}$. The results are shown as a profile representing the resistivity section in depth.

Samples for sedimentological analyses were collected from the east part of the excavation area, next to the Dermen Dere ravine (trenches D5 and D6), from the ravine itself, and from the right bank of the Maritsa River, at the east edge of the modern village of Nova Nadezhda, in order to find out whether the site was influenced by sedimentation in the ravine or it was flooded by the Maritsa river during the early periods of human occupation.

\section{RESULTS}

\section{Macroscopic description of trench D5, south profile, from top to bottom (Fig. 3)}

- 0-60 cm: grayish alluvial clays with massive texture, with small polygonal cracks; few archaeological materials; color index 10YR5/2 (grayish brown); sample 7;

- 60-130 cm: gray clays, sandy, with prismatic cracks; color index 10YR5/2 (grayish brown); sample 6;

- 130-185 cm: gray clay, sandy to clayey sands, massive, with small gravel and archaeological materials; color index 10YR5/2 (grayish brown); sample 5;

- $185-250 \mathrm{~cm}$ : gray clay, sandy, with large gravel and pebbles up to $12-15 \mathrm{~cm}$ and archaeological materials. The particles are angular to semi-angular, flat; the orientation is sub-parallel to the layering; color index 10YR5/3 (brown); sample 4;

- 250-305 cm: yellow clay, sandy, with single gravels or pebbles (metamorphic rocks?) and quartz; color index 10YR6/3 (pale brown); sample 3;

- 305-310 cm: uneven lenticular layer of sand with gravel, well seen on the north profile, too; color index 10YR6/3 (pale brown); sample 2;

- 310-372 cm: dark gray clay with archaeological materials, slightly sandy; color index 10YR5/2 (grayish brown); sample 1.

\section{Macroscopic description of trench D6, south profile, from top to bottom:}

Deposits in the interval from the surface to $230 \mathrm{~cm}$ in this trench are similar to these from trench D5 between surface and $250 \mathrm{~cm}$.

- 230-240 cm: reddish sandy clay to clayey sand, massive, with small gravel; color index 7.5YR4/4 (brown); sample 9;

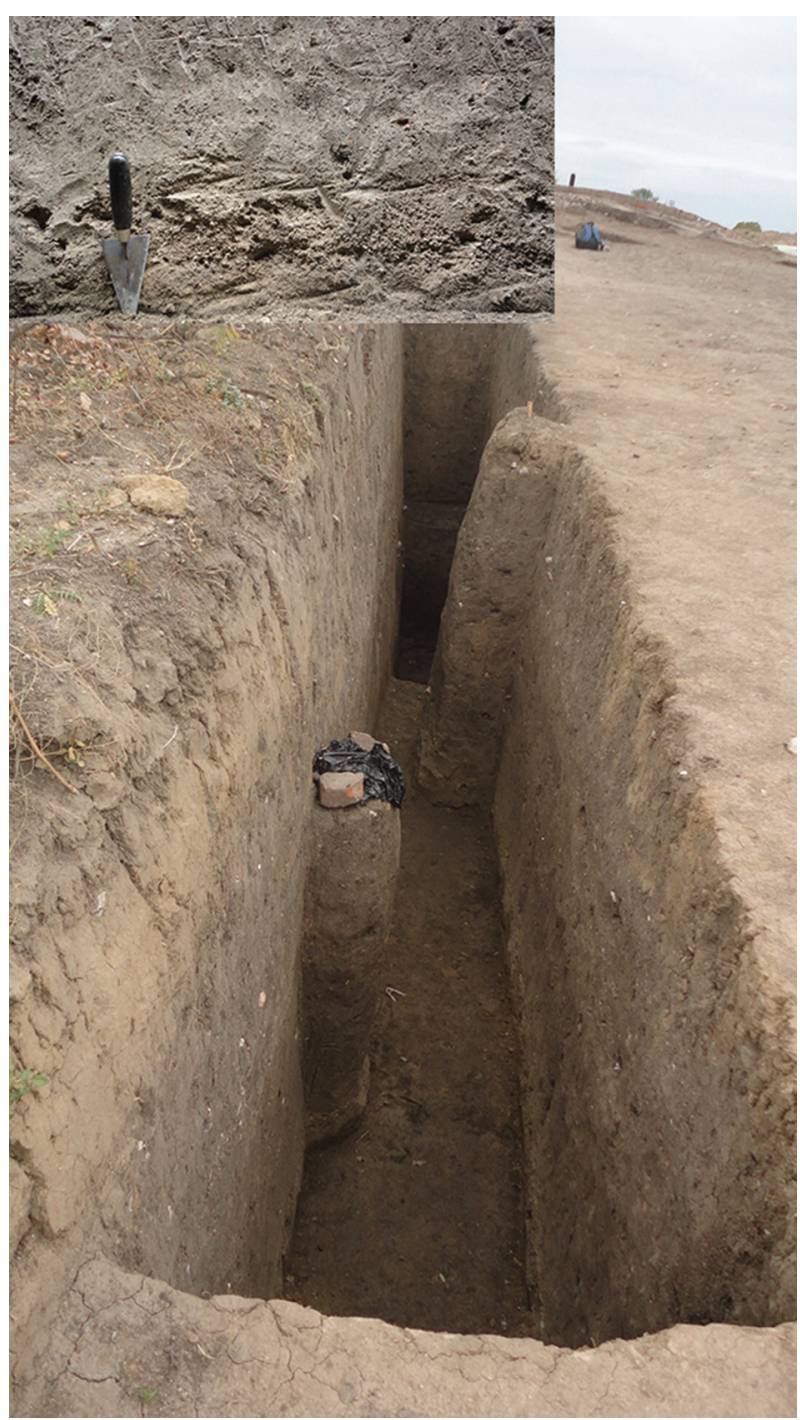

Fig. 3. General view of trench D5, with a close view of the sand with gravels (sample D5-2). 
- 240-260 cm: grayish clay, sandy; color index 10YR5/4 (yellowish brown).

\section{Grain-size composition}

Grain-size analysis shows that sediments in trenches D5 and D6 are represented by clayey sandy silts and clayey silty sands in the bottom. They are poorly and very poorly sorted.

Results are displayed in Fig. 4. According to their grain-size composition, sediments are referred to the class of mixed rocks: without prevalence of any grainsize class. The silt fraction is predominant (43-48\%), except for sample D5-2, which represents sand with gravel with clayey-silty matrix, and sample D6-9, which is sandy silt. The sediment from the Dermen Dere (labeled as 'stream 15') is sand with gravels and a very small amount of silt admixture.

The calculated statistical parameters (Table 1) show that sediments from trench D5 are generally very poorly sorted ( $\sigma_{1}$ varying between 2.42 and 3.24), except for sample D5-2, which is poorly sorted. The mean size of the sediment varies from 3.35 to $4.28 \varphi$ ( 0.22 to $0.35 \mathrm{~mm})$, with the exception of D5-2. Similarities between samples D5-2 and stream 15 are ob- vious: close values of $\sigma_{1}$ and negative values of $\mathrm{Mz}$ $-1.5 \varphi(3.5 \mathrm{~mm})$ and $-0.009 \varphi(2.23 \mathrm{~mm})$.

\section{Mineral composition}

The fine sand fraction $(0.063-0.126 \mathrm{~mm})$ is most characteristic for the mineral composition of sediments, as it contains all minerals that are present in a certain sediment. In order to understand whether the terrace hosting the archeological site was the product only of the Maritsa River floods or the nearby stream, a tributary of the Maritsa, has also flooded the site, three samples from the excavation area, the ravine, and the Maritsa were submitted to mineralogical analysis. The light fraction shows similar composition and amount of minerals for the three samples (Fig. 5).

The distribution of heavy minerals in the three samples, however, shows clear differences between the archaeological site (trench D5) and the Maritsa River, and similarities between the site and the Dermen Dere ravine (Fig. 6). In the sample from the Maritsa, opaque (ore) minerals dominate $(48.88 \%)$, followed by amphibole $(18.81 \%)$, epidote $(8.83 \%)$, and titanite $(5.86 \%)$. The fraction from the Dermen Dere ravine (stream 15$)$ is dominated by epidote $(38.55 \%)$, zircon

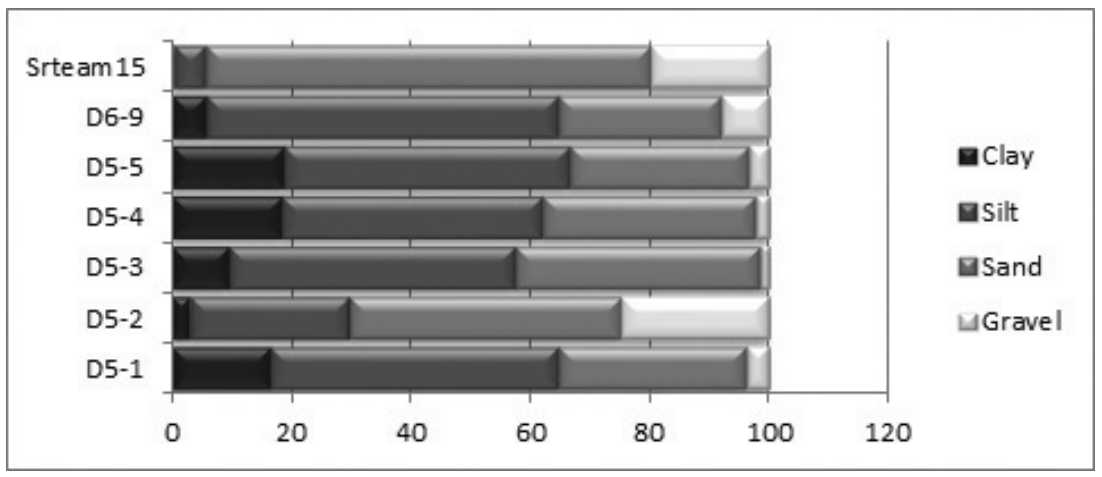

Fig. 4. Histogram of grain-size composition of samples from trench D5 and the Dermen Dere ravine (stream 15).

Table 1

Statistical parameters of grain-size distribution of samples from trench D5 and the Dermen Dere ravine (stream 15)

\begin{tabular}{lcccl}
\hline Sample & $\sigma 1$ & $\mathrm{Mz}$ & $\mathrm{Sk}$ & Verbal expression of statistical parameters \\
\hline D5-1 & 3.10 & 3.77 & -0.04 & Very poorly sorted, near symmetrical distribution \\
D5-2 & 1.92 & -1.50 & -0.34 & Poorly sorted, asymmetrical for the fine fraction \\
D5-3 & 2.42 & 3.35 & 0.00 & Very poorly sorted, near symmetrical distribution \\
D5-4 & 3.24 & 3.61 & 0.17 & Very poorly sorted, asymmetrical for the coarse fraction \\
D5-5 & 3.24 & 4.26 & -0.12 & Very poorly sorted, near symmetrical distribution \\
D6-9 & 3.03 & 4.28 & -1.06 & Very poorly sorted, asymmetrical for the fine fraction \\
Stream 15 & 2.32 & -0.09 & -0.03 & Very poorly sorted, near symmetrical distribution \\
\hline
\end{tabular}




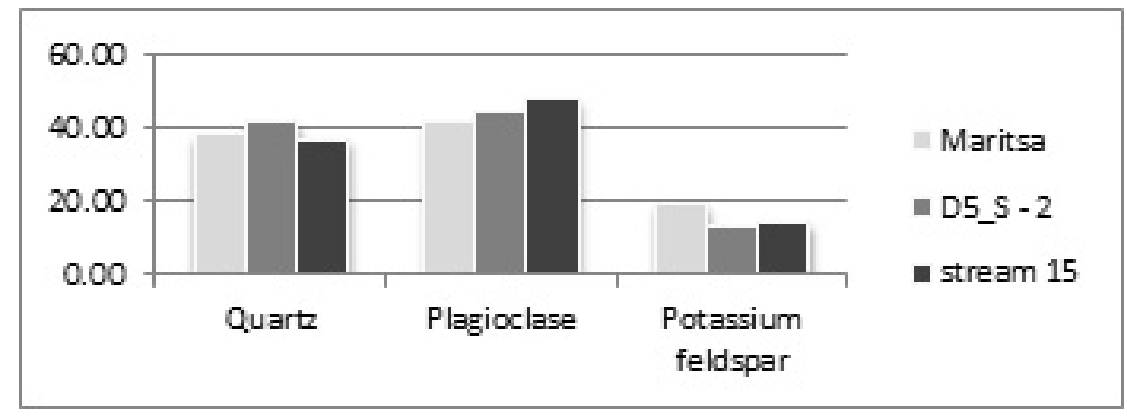

Fig. 5. Composition of the light mineral fraction of samples from trench D5, the Maritsa River, and the Dermen Dere ravine (stream 15).

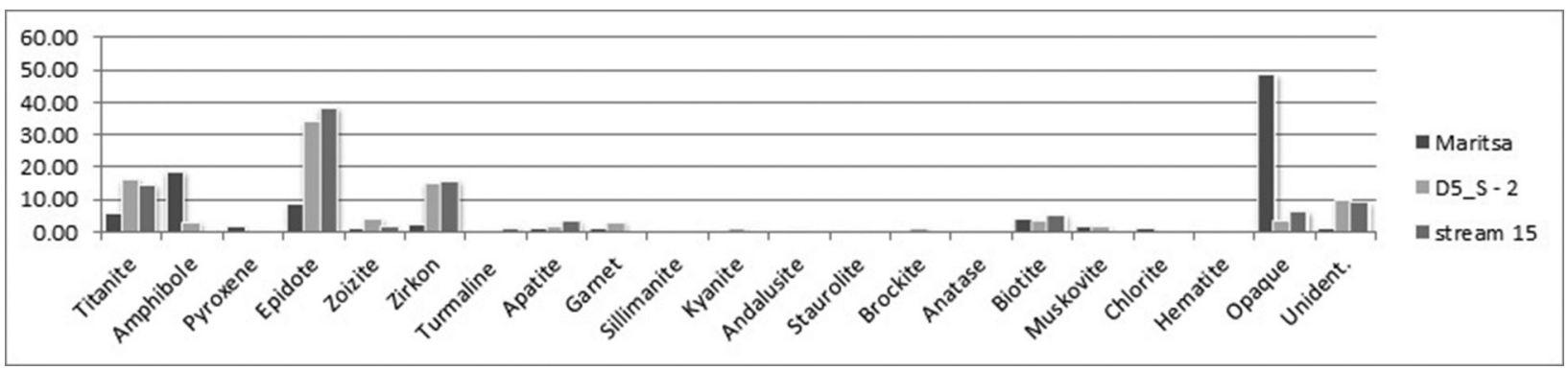

Fig. 6. Composition of the heavy mineral fraction of samples from trench D5, the Maritsa River, and the Dermen Dere ravine (stream 15).

(15.99\%), and titanite $(14.63 \%)$, and the opaque minerals here are $3.45 \%$. Dominant minerals in the heavy fraction from trench D5 sample 2 are the same: epidote (34.15\%), zircon $(15.20 \%)$, and titanite $(16.31 \%)$, and opaque minerals are $3.45 \%$.

\section{D Resistivity profiling}

2D resistivity images show a layered structure of the sediments (Fig. 7). The uppermost layer is represented by deposits with low resistivity of less than $20 \mathrm{Ohm}$ $\mathrm{m}$. It is interpreted as the upper clayey-silty soil. Below this, a layer with higher resistivity between $50 \mathrm{Ohm}-\mathrm{m}$ and $140 \mathrm{Ohm}-\mathrm{m}$ can be outlined. It is traced on Profile 1 between meters 0 and 176, and between $48 \mathrm{~m}$ and $110 \mathrm{~m}$ on Profile 2. Its thickness varies from $2 \mathrm{~m}$ to $5 \mathrm{~m}$ on Profile 1, and about 1-1.5 m on Profile 2. This layer can be interpreted as the sand deposits of the terrace. The highest resistivity materials are also observed near the surface at meters 88-94 and 160-170 on Profile 1, and at $42-46 \mathrm{~m}$ on Profile 2. An area showing low resistivity of less than $20 \mathrm{Ohm}-\mathrm{m}$ is observed below on both profiles. It is interpreted as groundwater rich sediments measuring ca $15-17 \mathrm{~m}$ thick on Profile 1 and ca 10 $12 \mathrm{~m}$ on Profile 2. At the bottom of the profiles, an area with resistivity between $20 \mathrm{Ohm}-\mathrm{m}$ and $50 \mathrm{Ohm}-\mathrm{m}$ is detected and interpreted as bedrock.

\section{DISCUSSION}

The comparison between results of the grain-size analyses of sand from the Dermen Dere ravine and sample D5-2 from trench D5 shows the similarity between them. The character of cumulative curves and statistical parameters gives grounds to suggest that these layers were deposited by the tributary stream in the Dermen Dere ravine. This is strongly supported by results of the mineralogical analysis of heavy fraction. The heavy mineral associations in sediment sample D5-2 from the site and from the ravine are the same (epidote-zircon-titanite), whereas ore minerals prevail in the sediments from the Maritsa, and the dominant heavy transparent mineral is amphibole. Another point for the presence of ravine sediments at the archeological site is the identification of relatively high resistivity deposits near the surface at $160-170 \mathrm{~m}$ on Profile 1 , which is located very near to trench D5, that can be interpreted as an incision from the ravine.

Two small incisions of materials with higher resistivity (above $50 \mathrm{Ohm}-\mathrm{m}$ ) are observed in the western part of the resistivity images of Profile 1 in the intervals $40-50 \mathrm{~m}$ and $88-94 \mathrm{~m}$, and $42-46 \mathrm{~m}$ on Profile 2 . As these areas are too far from the Dermen Dere ravine, it seems that, at certain times, the Maritsa has also flooded the site. 

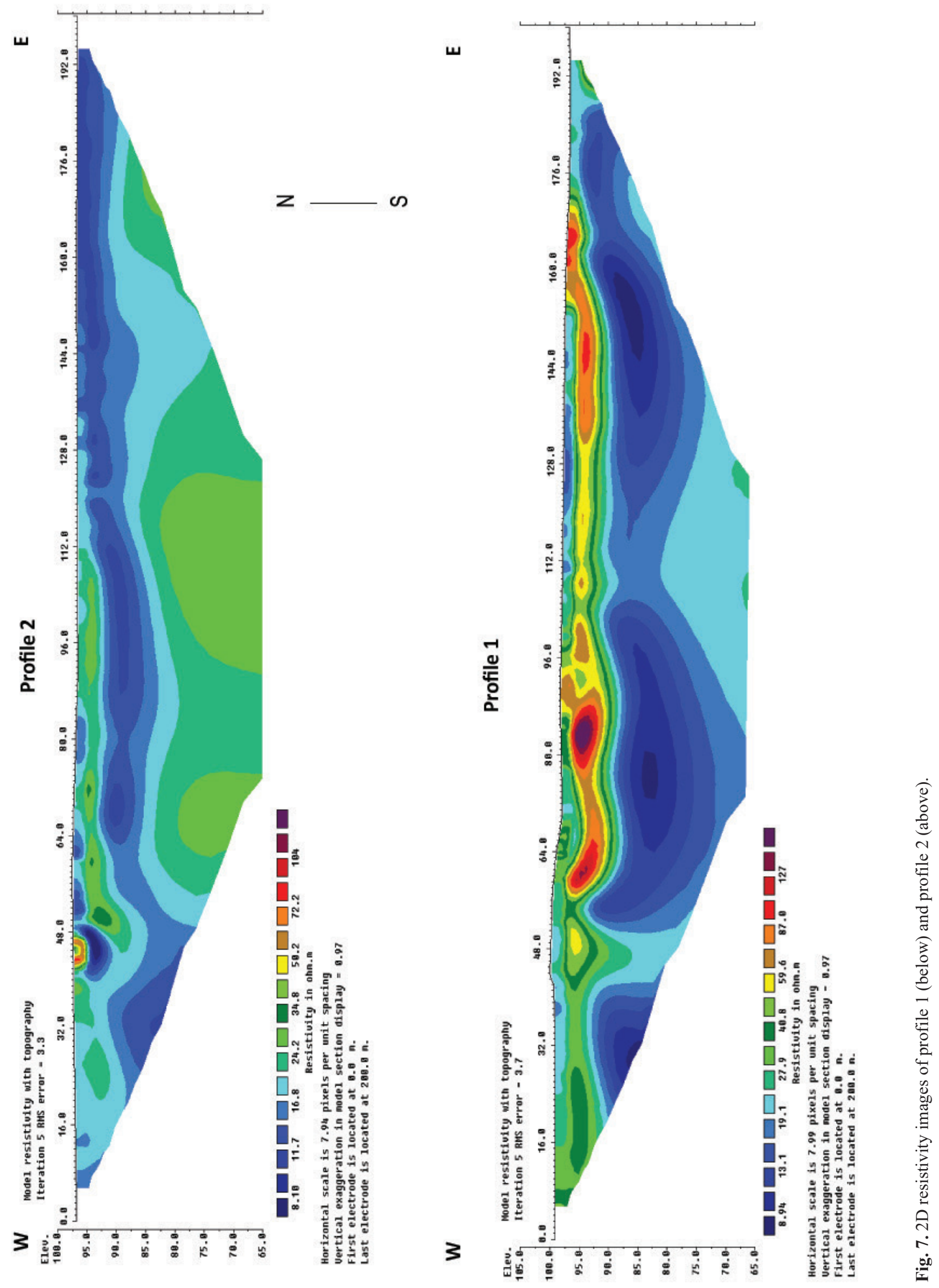


\section{CONCLUSIONS}

The results of the mineralogical analyses, combined with the grain-size analyses and data from the 2D resistivity profiling, suggest that the Dermen Dere stream has flooded the east part of the prehistoric site of Nova Nadezhda, whereas the west part of the site was more accessible to floods by the Maritsa River.

The presence of materials brought by the Dermen Dere stream in the archaeological deposits in the east part of the site also shows that the stream bed has shifted to the east since the sixth and fifth millennia BC.

\section{REFERENCES}

Angelova, D., Nenov, T., Spiridonov, H. 1993. The river terraces of the Maritza river and the Quaternary development of High Thracian lowland. Review of the Bulgarian Geological Society 54 (3), 41-59.

Bacvarov, K., Todorova, N., Katsarov, G., Petrova, V., McSweeney, K. 2016. The dead and the nested pots: an Early Neolithic ditch burial at Nova Nadezhda, Bulgarian Thrace. In: Bacvarov, K, Gleser R. (Eds), Southeast Europe and Anatolia in prehistory: Essays in honor of Vassil Nikolov on his 65th anniversary. Universitätsforschungen zur Prähistorischen Archäologie 293, Rudolf Habelt, Bonn, 149-159.

Boyanov, I., Goranov, A., Shilyafova, J., Ruseva M. 1993. Geological map of the Republic of Bulgaria in scale 1:100 000, Dimitrovgrad map sheet. Committee of Geology, Company for Geophysical surveys and Geological mapping, Sofia. Kojumdgieva, E., Dragomanov, L. 1979. Lithostratigraphy of Oligocene and Neogene sediments in Plovdiv and Pazardzhik district. Palaeontology, Stratigraphy and Lithology $11,49-61$.

Krastev, N., Dobrev, T., Dragomanov, L. 1992. Basic morphostructural features of Pre-Paleogene basement of the Upper Thracian depression and its cover. Geologica Balcanica 22 (4), 57-89.

Zagorchev, I. 1992. Neotectonic development of the Struma (Kraistid) Lineament, southwest Bulgaria and northern Greece. Geological Magazine 129, 197-222.

Wentworth, C.K. 1922. A scale of grade and class terms for clastic sediments. Geology 30, 377-392. 